that of radio becoming an even more effective means of mass communication is considerably enhanced if the Commission is conscious and open about the authority exercised. ${ }^{x x}$

The standard of public interest, convenience and necessity gives the Commission the discretion necessary to carry out its obligations. Its use provides the conceptual frame for regulation required by the concomitant factors of technological limitations on the number of stations and the desire to prevent one-sided control over an important means of mass communication.

\title{
ANCIENT RULES AND MODERN TRUSTS
}

\section{I}

Motivated by a deep distrust of the ability of future generations to preserve property interests, testators frequently attempt to retain control of their wealth and to project their authority over its use and distribution far beyond the grave. ${ }^{\mathrm{I}}$ Not only does the law furnish elaborate devices by which such control may be carried out, but the possibility of large tax savings provides a strong additional incentive for the creation of multiple generation gifts. ${ }^{2}$ The number of successive estates which may be set up is limited by the rule against perpetuities. However, since future interests are now invariably created by the use of trusts, ${ }^{3}$ the restraints on land at which this rule was originally directed are

${ }^{7 x}$ Advocates of government-controlled radio in Great Britain point with scorn at the American system whereby private advertisers set the standards of radio content. In his recent book, British Broadcasting (I950), R. H. Coase quotes one supporter of the British system as saying (at I33), "It is one of the many advantages of the public ownership and control of the radio that certain standards have been maintained. We have kept out the advertiser of pills and corn-plasters and suchlike who holds the American radio in the hollow of his hand. ..."

I The ability to control property after death has been referred to as "the greatest latitude ever given in the history of the world to the volition and caprice of the individual." Maine, Village Communities 42 (r889). For a comprehensive outline of the economic and psychological motives for which donors "transmute their volition into dead hand restraints" and of the general community objectives in policing such restraints, consult McDougal and Haber, Property, Wealth, Land $246-49$ (1948). The various legal devices by which these restrictions may be carried out are discussed in Scott, Control of Property By the Dead, 65 U. of Pa. L. Rev. 527, 632 (I917).

2 See text infra p. ror.

${ }^{3}$ As the basis of wealth shifted from land to intangible property interests, the possibilities of dissipation and mismanagement of family holdings increased, and the use of the trust as a device for the transmission of wealth from generation to generation eventually became almost universal.

The English Property Act of 1925 made all future interests equitable interests. Now the only legal freehold estate in English law is the fee simple absolute in possession. If a series of future interests is created, the legal fee simple title vests in the life tenant in possession in trust for all subsequent beneficial owners. Cheshire, Modern Real Property 470-7I (6th ed. I949).

In Illinois, where it is necessary for the conservation, preservation, or protection of real estate subject to legal future interests, a remainderman may petition a court of equity to appoint a trustee with authority to sell, mortgage, or lease the property or to take any other measures necessary for its preservation. Ill. Rev. Stat. (Bar ed. I948) c. 22, $\$ 50$. 
largely nonexistent. The owner of a legal life estate or defeasible interest subject to a transfer over on a future contingency was far more reluctant to invest in his property than one whose interest was absolute, since he might not obtain the full benefit of the improvements which he had made; 4 and unless the legal power to convey a fee was vested in one person, property was rendered less alienable. The rule against perpetuities, by requiring all interests to vest within lives in being and twenty-one years, limited the period during which absolute ownership could be postponed and thereby operated to remove restraints which otherwise might have been prolonged indefinitely. ${ }^{5}$ When a trust is created, how-

4 Gray, The Rule Against Perpetuities 253 (3d ed. 1915). It is conceivable, of course, that the objective of the rule against perpetuities in this regard could have been accomplished by giving the life tenant a right in fee to the benefits of the improvements which he had made. However, the difficulty of measuring the value of this interest and the complications in title which would have resulted would appear to have rendered such a scheme unfeasible.

5 The effect of the rule was indirect; by requiring all interests to vest within a specified period it assured that all future interests would become one present interest in fee within a limited time. The use and alienability of property were impeded by the existence of future interests per se; vested future interests were often as objectionable to the policy behind the rule as contingent interests. Assume, for example, that property was devised to A for life, $B$ for life, remainder to either $D$ or $E$, whoever first became minister; assume also that all four parties were alive at the death of the testator. To convey a fee the concurrence of four parties would be necessary. When $D$ became a minister, i.e. when all interests became vested, the alienability of property was not facilitated merely because the fee could then be conveyed by the joint action of only three parties. Although theoretically such a conveyance was possible, it was obviously more difficult for three persons to convey property than it was for one, and the property would not be entirely free from these indirect restraints until A and B died and D's interest became absolute. As of the time the devise was originally made, this would have to occur within lives in being and twenty-one years.

Many courts have considered not when future estates will begin, but how long it would be before an absolute interest could be conveyed. Since contingent interests are theoretically alienable it would be legally possible to convey a fee whenever there were no unborn remaindermen. Therefore, it has frequently been held that alienable contingent interests (those which, with all prior interests, could be released to convey a fee) were not subject to the rule against perpetuities, that the rule is satisfied by the existence of persons who by their joint action could convey a fee. Gray strongly objected to the statutes and cases which formulated the rule in this way, realizing that this would tend to extend the period during which property could be tied up, since from a practical point of view, it would often be difficult to obtain the consent of all interested parties when an attempt to convey a fee was made. Gray, The Rule Against Perpetuities 252-63 (3d ed. r915).

Some states have adopted statutes phrasing the rule in terms of postponing the absolute power of alienation. Although courts have had great difficulty in applying such rules due to an inability to forget the concept of "vesting," it is submitted that stating the rule in this way indicates more clearly the aims at which the rule was directed. All of these statutes have been modelled after the New York legislation of 1832 which states that the power of alienation may not be suspended longer than two lives in being. "The absolute power of alienation is suspended when there are no persons in being by whom an absolute fee in possession can be conveyed. Every future estate shall be void in its creation, which shall suspend the absolute power of alienation ... for a longer period than two lives in being at the creation of the estate." N.Y. Real Property Law (McKinney, Igr8) $\$ 42$. For the history and the difficulties in applying the New York statute, see Fourth Supplemental Report of the Commission to Investigate Defects in the Law of Decedent's Estates, N.Y. Legislative Document No. 55 (1933), reprinted in combined Reports of the Decedent Estate Commission. Compare Fraser, Rationale of the Rule Against Perpetuities, 6 Minn. L. Rev. 560 (1922). 
ever, the legal fee vests immediately in the trustee. Settlors ordinarily confer broad discretionary powers on trustees to sell, lease or mortgage, ${ }^{6}$ and even where such powers have been expressly withheld, they may still be exercised if a court of equity deems it necessary.7 The alienability and development of trust property, therefore, is in most cases unaffected by the existence of equitable future interests, whether vested or contingent. The caution usually exercised by trustees may impose practical restraints on alienability, but since most trust property now consists of securities rather than productive assets (such as land), these restraints have become relatively unimportant.

The rule against perpetuities may once have operated effectively to free land from the restraints imposed by aristocratic family dynasties, ${ }^{8}$ but, although the rule still applies to the legal and equitable interests set up by a trust, its justifcations have disappeared. Not only does it fail to enforce any public policy, but it serves to complicate the drafting of trust instruments. The validity of dispositions has been made to depend on the draftsman's facility in manipulating an archaic formula. ${ }^{9}$ The rule at one time also served to limit the duration of

${ }^{6}$ Carey and Schuyler, Illinois Law of Future Interests 6or (I94r).

7 See In re Pulitzer's Estate, 249 N.Y. Supp. 87 (I93I), aff'd I39 N.Y. Misc. 575, 260 N.Y. Supp. 975 (1932). Although the will prohibited the trustees from disposing of stock, the court authorized a sale to protect the beneficiaries from the serious loss which was bound to result from the continued operation of the corporation.

8 The development of the free alienability of land and the power to create future interests, and the consequent evasion of the incidents and services of feudal tenure, represented the triumph of the family as the primary property-owning unit. The rule against perpetuities, on the other hand, represented a limited protection of the individual property owner against restraints which arose from the attempts of family heads to project their will into the future. See Plucknett, A Concise History of the Common Law 49I-5I5 (1948). As it was formulated in the early seventeenth century, the modern rule against perpetuities also represented the economic policy of society against permitting land to be withdrawn from circulation for too long a period. It was first necessitated by the recognition of indestructible future interests. Pells v. Brown, Cro. Jac. $59^{\circ}$ ( 1620 ), held that a fee mounted upon a fee was not barrable by a common recovery. The modern rule against perpetuities was first announced in the Duke of Norfolk's Case, 3 Ch. Cas. I (r682).

For the development of the rule, see Gray, The Rule Against Perpetuities $\$ \S 123-200$ (3d ed. Igr5).

9 The authorities appear to be more concerned with defeating the objectives of the rule than with making it effective. Professor Leach has pointed out that "anything a testator is likely to want can be done within the limits of the Rule Against Perpetuities." Leach, Perpetuities in a Nutshell, 5I Harv. L. Rev. 638, 668 (1938). Professor McDougal, however, has severely criticized the rule. "[T]he principal doctrinal statements of the rule are either tautologous or metaphorical, bearing little relation to observable facts and making completely unrealistic assumptions about cause and effect in determining forbidden consequences; these principal doctrinal statements purport to make reference to, and to guide and justify the making of decisions about the whole range of practical problems inherent in the variegated objectives of donors in the wealth transmitting process ... the policies which might be thought to be relevant in terms of their relation to clarified community objectives, to each of the specific objectives of donors are as a result hopelessly confused and poorly implemented. ..." McDougal, op. cit. supra note $\mathrm{I}$, at $25 \mathrm{r}$. Aside from a few cursory statements to the effect that the rule is aimed at preventing prolonged restraints on the fluidity of property, most other authoritative discussions of the subject appear to take its underlying policies for granted; 
trusts, but it was rendered ineffective even for this purpose by the recognition of indestructible trusts by which settlors could postpone the enjoyment of the trust principal far beyond the time at which all interests became vested. ${ }^{\mathrm{xo}}$ To limit the duration of these trusts, courts in several jurisdictions have formulated a new rule to the effect that a private trust may not be made indestructible for a period longer than lives in being and twenty-one years. ${ }^{\mathrm{x}}$ The measuring

see, for example, Carey and Schuyler, Illinois Law of Future Interests $\$ 475$ (I94I); 2 Simes, Future Interests $\$ 49^{\circ}$ (1936); Kales, Future Interests \& I2r (I920); Gray, The Rule Against Perpetuities ( $3 \mathrm{~d}$ ed. I9I5). There are a few exceptions, however; the objectives of the rule have been very clearly stated in Rundell, The Suspension of the Absolute Power of Alienation, I9 Mich. L. Rev. 235, 237-38 (r92r) and in Fraser, The Rationale of the Rule Against Perpetuities, 6 Minn. L. Rev. 560 (I922). Both writers, however, are silent as to whether the time limits imposed by the rule are adequate. Aside from the rather harsh statements by $\mathrm{McD}$ ougal, op. cit. supra note 9, and a few casual comments by Professor Leach in his Cases on Future Interests 893 (r935), the policy foundations of the present time limitations have not been adequately considered.

so Claflin v. Claflin, I49 Mass. I9, 20 N.E. 454 (1889). The testator left one-third of his estate to his son, $\$ 10,000$ to be distributed when he reached $2 I$, \$ro, 000 at age 25 , and the balance at age $3^{\circ}$. The son, just prior to his twenty-fifth birthday, brought an action to compel the trustee to turn the principal over to him on the ground that a cestui who is sui juris and who possesses an absolute indefeasible interest may call for the trust to be terminated. The court held, however, that to terminate the trust would be to defeat the intent of the testator and that the provision of the will postponing enjoyment after the son's interest had vested was valid.

English courts had reached the opposite result and permitted the trust to be terminated in Saunders v. Vautier, 4 Beav. $x_{5}$ (I84I). Gray criticized the Claflin decision on the ground that at common law it was against public policy to restrain a man in the enjoyment of property in which no one but himself had an interest; he claimed that the Massachusetts court had introduced a novel idea into the law- the inalienability of absolute interests. Gray, The Rule Against Perpetuities $\delta \delta$ I20, I2Ii ( $3 \mathrm{~d}$ ed. I9I5). The majority of American courts which have considered the problem, however, have followed the Claflin doctrine. See cases cited in 4 Bogert, Trusts and Trustees $\S 1002$ at note 52 .

Once all interests have vested, a provision postponing enjoyment does not violate the rule against perpetuities, since the rule is concerned only with the time at which future interests vest and not how long they may last. Assume property is given in trust to A for life, remainder in fee to A's first son, A having no children at the time the trust is created. There is a provision in the will or deed, however, that the property is not to be transferred to the son until he reaches fifty. The rule against perpetuities is not violated, since the son's interest must vest when he is born. Under the Clafilin doctrine, however, the trust in the example stated will continue twenty-nine years beyond the perpetuities period (the son's twenty-first birthday). Gray, op. cit. supra note I4, $\$ \S$ I2Ic-I2If; Carey and Schuyler, Mlinois Law of Future Interests $\$ 480$ (194I).

2x 2 Simes, Future Interests $\$ 557$ (1936); I Bogert, Trusts and Trustees $\S 218$ (I935). This rule has not as yet been clearly spelled out, but certain of its characteristics appear not to have been disputed by the authorities. A provision postponing enjoyment beyond the perpetuities period will not render the trust subject to external attack by heirs, devisees, or other persons whose interests are hostile to the beneficiary. Cleary, Indestructible Testamentary Trusts, 43 Yale L. J. 393 (I934). The whole trust will not be declared void, as is the case where the vesting rule is violated, but only as to those interests which last beyond the perpetuities period. The rule provides that the trust will be terminated any time after lives in being and twenty-one years only if the beneficiaries so desire. If the beneficiaries take no action to compel the trustee to convey the trust assets to them, the trust may continue indefinitely. The rule, therefore, does not directly limit the duration of trusts, but limits their prolonged in- 
period of the vesting rule was instinctively adopted by referring to any property interest which lasted too long as a "perpetuity." rz Courts have terminated trusts without realizing that in doing so they have been developing a new rule and have not been applying the rule against perpetuities. ${ }^{13}$ The "duration rule" has thus been formulated almost entirely by judicial instinct, and the problem of why it is undesirable to have wealth tied up in trust for long periods has not been carefully considered. Authorities on the subject have stated that the policy underlying the duration rule is the same as that which necessitated the vesting rule. ${ }^{x}$ Uncritical statements of this character and the failure to

destructibility. Morray, The Rule Against Prolonged Indestructibility of Private Trusts, 44 Ill. L. Rev. 467 ( 5949 ).

Other aspects of the rule have been less clearly defined. It appears uncertain, for example, when the measuring period of the rule should begin. Kales thought that the period should begin to run from the time that the trust was created. Kales, Rule Against Perpetuities, 2o Harv. I. Rev. I92, 202 ( 1907 ). Gray, however, felt that the period must be measured from the time at which the future interest involved vests. Gray, op. cit. supra note I4, \& I2I ii. See also Morray, The Rule Against Prolonged Indestructibility of Private Trusts, 44 Ill. L. Rev. 467, 473-74 (1949).

The meaning of the term "indestructibility" also appears to be unsettled. Most courts appear to have held that a trust is not indestructible if it may be terminated by the joint action of all beneficiaries. Morray, at $47 \mathrm{r}$. One writer, however, realizing the practical difficulties of securing collaboration when there are many beneficiaries, some of whom may not want the trust to be terminated, has defined as "indestructible" any trust which cannot be terminated by the action of a single beneficiary. Whiteside, Restrictions on the Duration of Business Trusts, 9 Corn. L. Q. 422, 43I (r924).

Carey and Schuyler have stated that there is no necessity for a rule limiting the duration of indestructible trusts at all. The Claflin doctrine "has always been applied with a view to the attainment of a wholesome purpose, i.e., to enable a testator to accomplish legitimate objectives." It is argued that property in trust is given fluidity by the invariable presence of powers of sale in trustees, or by the power of a court of equity to direct a sale when necessary. Moreover, it is contended that these factors, plus the fact that all interested beneficiaries and the trustee may terminate a trust at any time they so desire, demonstrate that there is no need for a rule to govern the life of trusts. Carey and Schuyler, Illinois Law of Future Interests 6or (194r). Professor Scott, although he discusses the vesting rule-and almost every other aspect of the law of trusts-doesn't even mention the rule against prolonged indestructibility. Scott, Trusts $\S 62.10$ (r939).

$\times$ See cases cited in $x$ Bogert, Trusts and Trustees $\$ 218 \mathrm{n} .55$ (I935) and also in Gray, The Rule Against Perpetuities $\$ \$ 235-46$ (3d ed. rgrs).

${ }^{13}$ Professor Simes points out that in its primary meaning a "perpetuity" was an inalienable interest and that whether the rule which has been applied to the duration of trusts "is the same rule as the one which restricts the creation of contingent future interests would seem to be largely a matter of words. If there is not one rule, there are two exactly similar rules." 2 Simes, Future Interests $\$ 490$ ( $(936)$.

${ }_{4} 2$ Simes, Future Interests $\$ 553$ (I936); Gray, The Rule Against Perpetuities $\S$ r2ri (3d ed. rgr5); Morray, The Rule Against Prolonged Indestructibility of Private Trusts, 44 Ill. L. Rev. 467, 469 (I949); Brownell, Duration of Indestructible and Spendthrift Trusts, 23 Corn. L. Q. 629,633 (I938).

The history of the New York statute, supra note 5 , has provided the basis for extensive discussion of the whole perpetuities problem. In 1932 the State Legislature passed an act restoring the common-law rule, which in effect would have extended the permissible duration of indestructible trusts. The act was vetoed by Governor Roosevelt, however, who recommended that a commission be set up to study the proposed changes. The hearings and findings of that 
reexamine questions of policy are unfortunate, for it is difficult to see just what policy is being effectively implemented by a rule which permits trusts to be made indestructible for a hundred years. ${ }^{15}$ If there is any justification for a rule limiting the duration of trusts it must be found by an examination of the function of the private trust in its present economic and social context.

II

The primary function of a trustee is to conserve, not to create, wealth. ${ }^{16} \mathrm{He}$ must invest in accordance with strict requirements prescribed by statute, by court decision, and by the terms of the trust instrument. Although trust funds have played an increasingly important role in the production of wealth, they have been limited to highly conservative, nonspeculative securities. ${ }^{17}$ Statutory and judicial preference has been given to government bonds and other fixed obligations; in many states the purchase of common stock by trustees has been strictly forbidden. ${ }^{88}$ Economists have long realized, however, that in an economy of fluctuating price levels it is important that a large portion of all investments take the form of equities. ${ }^{19}$ Since 1935 there has been little, if any, net equity investment either directly by individuals or by intermediary financial institu-

commission have been thoroughly recorded and it is interesting to note that although there was extensive discussion of complex technical problems, considerations of economic policy were, with one exception, completely ignored. The statement by Professor Butler of the Fordham Law School pointed out that the use of trusts had contributed to the freezing of assets and the withdrawal of money from the capital market and that this itself should be a sufficient reason not to extend the existing permissible period of trusts. Fourth Supplemental Report of the Commission to Investigate Defects in the Laws of Estates, N.Y. Legislative Document No. 55 (r933), reprinted in Combined Reports of the Decedent Estate Commission, at $637-39$ (1933). Of the many discussions, both in leading texts and major law review articles, which have dealt with the duration of trusts, Professor Butler's memorandum appears to be the only one in which the relation of the problem to questions of economic policy has been mentioned.

is Leach, op. cit. supra note 9, at 668.

${ }^{16}{ }_{2} \mathrm{Am}$. Inst. of Banking, Trust Business $46_{3}-64$ (1935). "The accumulation of wealth, and its preservation, are distinct functions of ten requiring distinct and different techniques. ... The trustee is almost entirely concerned with the latter. It is his function to conserve and not to produce." Headley, A Trustee in a World of Changing Values, 5 Law \& Contemp. Prob. 355,356 ( 1938 ). See also Stephenson, Living Trusts 289 ( 1928$)$.

${ }^{17}$ See 3 Bogert, Trusts and Trustees $\$ \delta 67 \mathrm{I}-80$ (I935); Legal Lists in Trust Investment 49 Yale L. J. 89 I (r940).

${ }^{8} 3$ Bogert, Trusts and Trustees $\$ 679$ (r935).

19 Hansen, Fiscal Policy and Business Cycles 34r (r94I); Jones, Facilitating the Flow of Savings Into Private Investment 33, 56 (r949) (unpublished doctorate dissertation, Department of Economics, University of Chicago). The general argument against debt financing is that in an industry in which price levels fluctuate, any temporary price decline is likely to produce insolvency for a corporation heavily loaded with debt. Even if insolvency is avoided, attempts to avert it may cause excessive depreciation of physical properties due to a lack of funds for maintenance and repairs. Simons, Federal Tax Reform, I4 Univ. Chi. L. Rev. 20, 65 (1946). This in turn results in expensive court proceedings and has an adverse psychological effect on the business community. 
tions, and practically all outside financing by corporations is presently being done by the issuance of bonds. ${ }^{20}$ Corporation and personal income tax structures are particularly conducive to debt financing, ${ }^{21}$ as is the desire to create leverage for common stock or to facilitate control by small groups of stockholders. ${ }^{22} \mathrm{Be}-$ cause of inflation and high corporate profits most post-war capital expenditures have been financed by the reinvestment of retained earnings; ${ }^{23}$ the ratio of equity to total corporate capitalization consequently has remained relatively high..$^{4}$ But present inflation cannot be relied upon to maintain existing equity ratios. Nor can it be assumed that the supply of capital from internal sources will continue to be adequate and that more outside equity investment would not be desirable. Should the present level of corporate profits decline, it is conceivable that to secure sufficient funds and still retain low debt ratios more corporations will be compelled to seek equities on the market. The amount of capital available for this purpose may not be sufficient if funds continue to be placed in trust.25

A more immediate problem, however, is the inadequate supply of capital available in any form for small and new businesses. ${ }^{26}$ The few equities purchased by trustees are invariably those of the highest quality which offer a minimum

${ }^{20}$ See Jones, op. cit. supra note 19 , at $47-48,56$. New corporate capital issues in 1946 , for example, were only 21 per cent common stock; in I947, I3 per cent; and in the first nine months of 1948,9 per cent.

${ }^{2 x}$ Corporations heavily financed with bonds may realize substantial tax savings, since, in computing their tax base, interest is deductible from gross income while dividends are not. Int. Rev. Code $\S 23$ (b), 26 U.S.C.A. $\$ 23$ (b) (1940). Moreover, the redemption of bonds is considered a return of capital to the bondholder rather than ordinary income. Tax savings result primarily, of course, from the special rate on capital gains and the provision for a steppedup basis at death. There are greater diffculties in achieving this result in the case of stock. See Stockholder Realization of Corporate Earnings and the Income Tax, I7 Univ. Chi. L. Rev. 338 (I950). In addition a penalty under $\S$ IO2 might be more easily avoided by insisting that the accumulated earnings were being retained to redeem the bonds. See generally Schlesinger, "Thin" Incorporations, 6I Harv. L. Rev. 50 (1947).

22 SEC, Investment Trusts and Investment Companies, pt. 3, c. V, pp. 7-39 (I939).

${ }^{23}$ In 1948 internal sources provided 65 per cent of corporate funds, as against 53 per cent in 1947. Council of Economic Advisers, Economic Report of the President: The Annual Economic Review Ig (rg49). Corporate income has also been high in relation to debt charges, and corporations generally are now probably in a safe position to finance replacements and expansion by issuing bonds. Jones, op. cit. supra note $\mathrm{g} g$, at $44-45$.

24 The relation of equity to total funds in manufacturing corporations was 74.8 per cent in 1939 , and 69.5 per cent at the end of 1947 . Jones, op. cit. supra note I9, at $47-48$.

${ }^{25}$ It is difficult, of course, to estimate the extent to which trusts would limit the supply of equity capital available for larger firms. The total amount of outside financing by corporations has rarely exceeded two billion dollars in any one year, and it is possible that equity capital for larger firms, if needed, could be made available in sufficient quantity by the extension of the prudent man rule for trustees and by easing the restrictions on life insurance investment. TNEC, Savings and Investment, pt. 9, p. 3729 (I939). See note 33 infra.

${ }^{26}$ Special Committee to Study Problems of American Small Business, Future of Independent Business XIX (r947). 
risk. ${ }^{27}$ If the capital requirements of new and small businesses are to be met by private investment, it would appear desirable either to facilitate more active investment by trustees or to limit the volume of savings being placed in trusts. ${ }^{28}$

The inflated cost of living in recent years has created sentiment among professional trustees to the effect that the purchasing power of beneficiaries ought to be maintained."9 Common stocks have, therefore, been looked upon with greater favor, $3^{30}$ and measures which have tended to increase the powers of trustees to purchase equities are gradually being adopted. The statutory list of permissible investments is being eliminated in many states in favor of the "prudent man" investment rule. ${ }^{3 x}$ In addition, legislative provision has been made in numerous jurisdictions for common trust funds, which have furnished a device for lower administrative costs and for greater diversification of investments. ${ }^{32}$ Moreover, trustees are more frequently being granted broad invest-

i) See note 33 infra..Existing regulations have been regarded as a serious detriment to the flow of savings into outlets where they are most needed. Shattuck, A New Approach to the Prudent-MIan Rule for Truist Investment, 23 Trust Bull. 28, 35-36 (Nov. I943); Stephenson, Studies in Trust Business 23I (1938); TNEC, Savings and Investment, pt. 9, pp. 3729-34 (1939).

If the use of the trust device were to be limited, a larger portion of individual savings would in all probability be placed in the control of life insurance companies. Although money held by life insurance companies is technically not held in trust, since there is no segregated res, functionally there appears to be little difference. The investment problems of both are practically identical, and whatever limitations may be necessary to limit the volume of savings flowing into one must of necessity be applied to the other. The statutory restrictions on life insurance investment closely parallel restrictions on the investment of trust funds. See Statutory Regulation of Life Insurance Investment, 57 Yale L. J. I256, 1259 (1948).

28 Of the $\$ 8.8$ billion of personal savings in $1947, \$ 7.7$ billion was put in institutional forms of saving. Jones, op. cit. supra note 19 , at 30 . The proportion of this sum which was placed in trust funds is not definitely ascertainable. The total amount of funds held by trustees, however, was estimated in 1939 to be S5 $^{\circ}$ billion. TNEC, Savings and Investment, pt. 9, p. 3729 (r939).

2) Although a trustee is charged with conserving the corpus, he is not expected to conserve the "value" of the principal, but only the res-the actual subject matter of the trust. For most purposes of trust accounting, however, what is known as the "quantum theory" has been in the ascendency. According to this view the trust corpus is not a "thing" but a "value." "It may be suggested that it is but an extension of the quantum theory to require a trustee to maintain a value measured in terms of purchasing power rather than of the monetary unit." Headley, A Trustee in a World of Changing Values, 5 Law \& Contemp. Prob. $355,363,365$ (1938). Such view has not, of course, been legally recognized.

.30 MicCarrol, Common Stocks for Trust Investment, 23 Trust Bull. 3.4 (May, 1944); Riddle, Trust Investments: Their Extent and Some Related Problems, 5 Law \& Contemp. Prob. 339,352 at note 1o (1938). Cowdrey, Investment Policy for Trustees, $8_{5}$ Trusts and Estates 545,547 (1947).

${ }^{35}$ As of June, 1945 the prudent man rule existed by statute in nine states; and by court decision in eight others. Box Score on Trustee Investment Powers, 80 Trusts and Estates 552 (1945).

32 By 1945 , twenty-tive states had adopted common trust fund enabling statutes. 80 Trusts and Estates 445 (1945). Institutionalized Trusteeship: Avenues of Compensation Reform, 58 Yale L. J. 924, 935 (1949); Headley, Uses and Limitations of Common Trust Funds, 23 Trust Bull. I7, 22 (Nov., 1943). 
ment powers in trust instruments. Despite these trends the proportion of total trust assets invested in speculative securities is still low. ${ }^{33}$ It appears evident from the nature of the trust relationship that this will continue to be the case, for even where these reforms have been adopted it is still a fundamental rule of trusteeship that a fiduciary's primary concern is the safety of the trust principal. ${ }^{34}$ Fear of surcharge causes him to act with extreme caution at all times. Investment at too high a rate of return may indicate that he has been speculating, a practice which is universally condemned:35 Thus he may be penalized for attempting to earn a high return, whereas he has nothing to lose, and will be considered as having acted wisely, if he buys government bonds and highly secured real estate mortgages..$^{36}$ Therefore, despite attempts to abolish restraints on the type of securities a trustee may purchase, it is highly improbable that risk capital will be furnished to any great extent by trustees in the future. The equities that they buy will continue to be those of large established enterprises with long records of regular dividend payments. ${ }^{37}$ The need for more risk capi-

33 Undoubtedly trustees have purchased more equities in states where the prudent man rule exists than in legal list states. The reports of corporate trust companies in Massachusetts, where the prudent man rule has been in effect since 1830, show that 41.8 per cent of their trust funds was invested in common stock. In New York (a legal list state) 22 per cent was invested in common stock. 24 Trust Bull. I4, I5 (Sept., 1944). Although information is not directly available as to the types of stock held, it is extremely doubtful whether trustees have purchased anything other than "blue chips." Writers who approve common stocks for trust portfolios unanimously recommend that great care should always be exercised so as to make certain that the security being purchased is of the highest quality. "[A] well-established business, financial strength, demonstrated earning capacity, a good record of dividend payments, capable management, and some prospects for growth and improvement in position . . . are almost prerequisite for a healthy equity investment." Chapman, Investing Trust Funds Under the Prudent-Man Rule, 23 Trust Bull. 2, 7 (April, I944). See also 2 Am. Inst. of Banking, Trust Business 169 (1935). Common trust funds also tend to increase the amount of common stock purchased by trustees; small accounts, which otherwise might prove difficult to invest at all, may be pooled for purposes of investment, and since greater diversification is thereby possible, more equities will be purchased. But again the equities which are bought are invariably "blue chips." "A common trust fund should never harbor a security which would not be bought for a single trust of like size." Headley, Uses and Limitations of Common Trust Funds, 23 Trust Bull. I7, 23 (Nov., 1943). To the same effect see Hurley, Formulation of Investment Policy for Common Trust Funds, 80 Trust and Estates 296, 298 (1945).

Since the corporations which have issued these safe securities usually acquire funds for capital expenditures from internal sources, it is usually the smaller enterprise and the new developing business which demand the funds of the capital market. The problem has not been solved, nor will it be solved, merely by permitting trustees to acquire more equities.

${ }^{34} 3$ Bogert, Trusts and Trustees $\$ 612$ (1935).

35 Headley, op. cit. supra note 29 , at 365 .

${ }^{36}$ Requiring corporate trustees to publish the rates of return on their investments might possibly make beneficiaries more aware of the inadequate investment services which trustees perform.

37 See note 33 supra. Riddle, Trust Investments: Their Extent and Some Related Problems, 5 Law and Contemp. Prob. 339, 353 (1938). In regard to life insurance companies it has been suggested that if insurance funds can be diverted into equities the degree of control over industry which would result would in all probability necessitate government supervision. Statutory Regulation of Life Insurance Investment, 57 Yale L. J. I 256, 1274 (1948). The fact 
tal, since it cannot be met by savings held in trust, requires that the possibility of limiting the amount of funds flowing into trust be considered. Since individuals may themselves invest as conservatively as trustees, reforms aimed at limiting the use of trusteeship may be of no value in stimulating more active investment. ${ }^{8}$ Measures are currently under consideration, however, which have as their objective the promotion of greater risk-taking by individuals. ${ }^{39}$ Aside from these measures, the extent of any unwillingness on the part of individuals to take risks cannot be determined until limitations on the use of the trust device have been enacted and tried.

\section{III}

A basic factor causing the huge flow of funds into the hands of trustees is the present gift and estate tax structure. Multiple generations gifts are taxable only once and huge savings are thereby made possible through the elimination of subsequent transfer taxes..$^{0}$ The bargain rate on gifts ${ }^{4 \mathrm{I}}$ encourages donors to dispose of at least part of their wealth during lifetime, and the desire to postpone actual receipt of the gift by the donee undoubtedly causes many of these gifts to be executed by the use of a trust..$^{z}$ Additional tax savings may accrue to the beneficiary if his income may be split so that part of it is taxed to him

that trustees and life insurance companies are usually required to diversify their investments could operate to prevent concentration. On the other hand, diversification is usually required only of the funds in individual portfolios, and the amount of stock controlled by an entire trust company might conceivably be great.

${ }^{38} \mathrm{It}$ is maintained, for example, that the bulk of savings will come from people in middleincome groups who are more concerned with safety of principal than with gains that involve high risks. Council of Economic Advisers, op. cit. supra note 23, at 65 .

${ }^{39}$ Special Committee to Study Problems of American Small Business, op. cit. supra note 26, at $\mathrm{XTX}-\mathrm{XX}$.

10 "If, for example, A left $\$ 5,000,000$ to $B$, who left it to $C$, who left it to $D$, who left it to $E$, assuming that there were no marital deductions involved and that the property remained unchanged in value, four estate taxes would be imposed. $E$ would finally inherit $\$ 718,721$ or less than 15 per cent of the original estate. If, on the other hand, $B, C$, and $D$ had been given successive life estates with a final remainder to $E$, there would have been only one tax and $E$ would inherit $\$ 2,569,600$, or over $5 \circ$ per cent of the original estate." Lowndes, Introduction to Tax Planning for Estates, 27 N.C. L. Rev. 2, Io (1948). This is not only the major tax motive for the creation of trusts, but it is also an incentive to extend their duration.

4 Consult Lowndes, op. cit. supra note 40.

${ }^{43}$ Attempts to take advantage of the lower rates on transfers inter vivos have been subject to an increasing number of difficulties which have resulted in the inclusion of the gift in the donor's gross estate. The most recent examples, of course, are the cases of Comm'r v. Estate of Church, 335 U.S. 632 (r949) and Estate of Spiegel v. Comm'r, 335 U.S. 70I (r949). Gifts which are to take effect in possession or enjoyment at or after the death of the donor, or in which the trust is alterable, amendable, revocable, or terminable by the settlor alone or in conjunction with any other person, are all taxed as part of the donor's estate. The types of trust transfers which retain the advantages of inter vivos dispositions have been greatly limited, but a donor may still postpone the receipt of a gift until after his death, or make it contingent upon the occurrence of some future event other than his own death. See Church and Spiegel in Perspective, r6 Univ. Chi. L. Rev. 7 Ir (r949). 
personally and the remainder taxed to the trust. 43 Reform aimed at the abolition of tax distinctions which encourage the use of trusts may itself reduce considerably the volume of funds flowing into the control of trustees. 44 The extent to which it may also be desirable to impose limitations on the use of the trust device depends upon the force of the other incentives for the creation of trusts, upon whether the social and economic functions of trusteeship outweigh the advantages to be gained by keeping private savings in the hands of individuals, and upon whether alternative means can be found by which the present justifiable functions of trusteeship may be carried out. Tax reform, however, may be a necessary condition precedent to further curtailment of the use of trusts. Once the tax advantages of trusts have been eliminated, a major source of political opposition to legislation limiting the use of trusts will have been removed.

One of the primary motives for placing wealth in trust is the desire to provide security for one's dependents. 45 The private trust, with the restrictions surrounding the trustee, is a convenient device for those who wish to leave widows free of financial worries and to provide for the support and education of children. Leaving property to the management of elderly widows, incompetents, and minors would obviously be even less desirable economically than the use of a trust; where property is left to such persons, some device by which the responsibilities of management can be shifted appears to be necessary. However, legislation limiting the use of private trusts to the support of living beneficiaries of these three classes would allow the accomplishment of these objectives, while curtailing the adverse economic effects of trusteeship. $4^{6}$

${ }^{43}$ This can be accomplished in the case of a mandatory or discretionary accumulating trust by having the trustee accumulate trust income for periods of more than twelve months. Int. Rev. Code $\$ 162(b)$ (c), 26 U.S.C.A. $\$ I 62(b)(c)$ (I945). Until recently another motive for the use of a trust was the desire to retain control over income-producing property when, in order to effectuate income tax savings, ownership of that property was divided among members of the donor's family. The income from such property will now be taxed entirely to the grantor if he retains too great a degree of control. Helvering v. Clifford, 309 U.S. 33 I (1940); Int. Rev. Code $\$ \S 22(a), I 66,167,26$ U.S.C.A. $\$ \S 22(a), 166,167$ (I945). The practical importance of this problem was greatly diminished by the enactment of the split-income option in the Rev. Act of r948. Int. Rev. Code \& 5 I(b), 26 U.S.C.A. \$ 5 I(b) (Supp., I948).

${ }_{44}$ Tax reform would have little to do with smaller trusts since a settlor must have at least one hundred thousand dollars to be able to take advantage of the multiple generation gift tax saving. The increase in common trust fund legislation in recent years would seem to indicate that there are far more small trusts than previously.

45 Headley, A Trustee in a World of Changing Values, 5 Law \& Contemp. Prob. 355, 364 (1938); 2 Am. Inst. of Banking, Trust Business 464-68 (r935).

${ }_{4}^{6}$ In the case of minors termination would have to be made mandatory when they attained majority; a rule merely limiting prolonged indestructibility would allow the trust to continue if the beneficiary so desired. Two states have already adopted similar legislation. In Oklahoma trusts are limited to twenty-one years or the life or lives of beneficiaries; the trust is required to specify the duration intended. Okla. Stat. (x94r) tit. $60 \S \mathrm{I} 72$. In Louisiana an inter vivos or testamentary trust may last only ten years after the death of the author or ten years after the majority of any beneficiary who is a minor at the settlor's death. La. Stat. Ann. (Dart, I938) $\$ 985^{\circ} \cdot 4$. 
In addition to its function as a family security device, the private trust has been used as an alternative to outright ownership by mature persons competent to manage their own affairs who nevertheless for a variety of reasons wish to relieve themselves of the responsibilities of property management.47 Inter vivos trusts with the settlor as beneficiary are desirable, from the point of view of society, only to the extent to which they enable the beneficiary to engage in pursuits other than the management and investment of his own property..$^{8}$ The services performed by trustees for doctors, artists and teachers, for example, are perhaps necessary, but it is conceivable that if the trust device were unavailable for such purposes the same functions could be performed by property management agencies and investment counselors. Whether the same degree of protection afforded by trusteeship could be guaranteed is doubtful; whether it is desirable is uncertain. It has been suggested in another connection that traditional notions about protecting the owner of property in the full enjoyment of its benefits may no longer be strictly applicable when the benefits and responsibilities of ownership have been divided. 49 The extent to which property can be safely and competently managed without making the manager a trustee would at least appear to merit investigation..$^{50}$

172 Am. Inst. of Banking, Trust Business 468-70 (1935); Stephenson, Living Trusts 33-36 (I926); Jones, Facilitating the Flow of Savings Into Private Investment, op. cit. supra note I9, at I 23, points out that persons who own a large amount of wealth may desire to place a portion of it in trust so that they can take active risks with the rest.

${ }_{18}{ }_{2} \mathrm{Am}$. Inst. of Banking, Trust Business $46_{4}-65$ (1935). It might be argued from a purely theoretical point of view that whether the other activities in which such persons engage are socially and economically desirable can be determined only by the mechanism of the market and that these activities should not, therefore, be subsidized in any way.

49 The "traditional logic of property" as applied to the modern corporation has resulted in the notion that the profits of industry, as far as the law is concerned, belong entirely to the security holders and that it is in their interest that the corporation should be operated. "In the past, the ownership of business enterprise . . . has always, at least in theory, involved two attributes, first the risking of previously collected wealth in profit-seeking enterprise; and, second, the ultimate management of and responsibility for that enterprise. But in the modern corporation, these two attributes of ownership no longer attach to the same individual or group.... One traditional attribute of ownership is attached to stock ownership; the other attribute is attached to corporate control. Must we not, therefore, recognize that we are no longer dealing with property in the old sense? . . . Because an owner who also exercises control over his wealth is protected in the full receipt of the advantages derived from it, must it necessarily follow that an owner who has surrendered control of his wealth should likewise be protected to the full?" Berle and Means, The Modern Corporation and Private Property 338-39 (I932). It would seem to follow from what the above quotation implies that the owner of wealth who has not only given up control, but who in addition is unwilling to take risks in productive enterprise, should be afforded even less protection.

so Compare, for example, the devices by which the benefits and responsibilities of wealth may be separated under the civil law. $X$ can transfer property to $Y$ upon the condition that $Y$ will prudently manage the property for the benefit of $Z$ or carry out any other wishes of $X$. This technique reaches substantially the same result as does a trust, and yet there is no fiduciary relation between the holder of the property and the beneficiary. "The civil law does not impose upon the person on whom the charge is laid anything more than the bona fide performance of the duties expressly stipulated in the charge." Lepaulle, Civil Law Substitutes for Trusts, 36 Yale L. J. II26, II36-37 (I927). 
Lack of confidence in the ability of one's successors and the desire to perpetuate control of property long after one's children have attained their majority undoubtedly constitute other basic motives for the creation of trusts, ${ }^{5 x}$ but it has long been recognized that one man's vision is too limited to devise a property settlement flexible enough to meet the needs of future generations. ${ }^{22}$ Price fluctuations, rapidly changing tax laws, and the problems of principal and income distribution which arise upon birth, marriage, divorce, or death are all factors which indicate the absurdity of attempting to honor for too long a period the dictates of the dead. Moreover, distrust of beneficiaries and consequent attempts to deprive them of responsibility in the management and investment of property are conducive to an unhealthy suppression of individualism and self-reliance, particularly in trusts containing spendthrift provisions. ${ }^{53}$ Conceding that protection is required for minors, the advantage of having decisions as to the allocation of wealth made currently, rather than a generation before they are actually carried out, and the psychological advantage of placing responsibility for the making of those decisions on the present beneficial owners require not only that the entire doctrine of indestructible trusts be abolished, but also that any trust for the support of a minor be made mandatorily terminable upon the beneficiary's attaining majority.

The adverse effect of trusts on the supply of risk capital and the undesirable extent to which they have reduced individual responsibility in the management of wealth are sufficient justification for drastic limitations on the use of private trusts. Most of the objectives for which such trusts are created can be accomplished within a relatively short period; others can in all probability be satisfactorily carried out by other devices. The rule against perpetuities and the onehundred year limitation on the duration of indestructible trusts are entirely unrelated to present day economic conditions. Legislation limiting the use of private trusts to the support of incompetents, elderly dependents, and minors would, therefore, appear to be highly desirable; at the very least, such reform would rid the law of one of its most useless and confusing rules.

5x Morray, op. cit. supra note II.

52 Ibid.; Whiteside, Restrictions on the Duration of Business Trusts, 9 Corn. I. Q. 422 , 423 (I924).

53 "[T] $]$ he prevailing tendency among testators who have been able to amass substantial wealth to limit their children to the income only and to make the third generation the real beneficiaries is unworthy and unwarranted ... such desire on their part is predicated upon a degree of personal egotism in their own foresight, coupled with an unnatural distrust of the ability of their children to properly conserve their property interests . . . this tendency necessarily makes toward a suppression of individualism and self-reliance in the children. It reveals a plain and humiliating distrust on the part of the parent of their future habits and ability when the children are deprived of anything beyond the opportunity to receive and spend the income ... the parent has thus practically eliminated his children from any normal succession to his property. He has taken two turns at being the head of the family where the second turn belongs to his sons and daughters." Fourth Supplemental Report of the Commission to Investigate Defects in the Laws of Estates, op. cit. supra note I4 at $48 \mathrm{I}$. 